\title{
An attempt to assess the welfare of horses maintained in herd systems
}

\author{
Jadwiga Topczewska \\ Department of Animals Production and Poultry Products Evaluation, Faculty of Biology and Agriculture, University of \\ Rzeszów, Rzeszów, Poland
}

\begin{abstract}
The aim of the study was to assess the welfare, using the Welfare Quality criteria, of horses maintained in natural conditions. The study material was a herd of Hucul horses, consisting of 14 mares with offsprings and a stallion, maintained in a herd system on pastures. The research was conducted in the months of March, July and November in 2010 and 2012. Nutrition assessment was based on access to feedstuff, water, including their state. Analysis of levels of maintenance involved evaluating prevailing weather conditions, stocking rate as well as horses' freedom of movement in the delineated land area. Assessment of the herd's health condition was based on interviews with the supervising veterinarian. Horses' behaviour was assessed through observations that relied on their social, affiliative and agonistic behaviours. The condition of the horses was influenced by the period of year, with the best being in November $(P \leq 0.01)$. Maintenance conditions and exploitation affected the herd's state of health, with no illnesses or injuries being reported over the analysed period. Seasons of the year had impacts on the horses' behaviour $(P \leq 0.01)$. In summer, grazing took place in the late evenings and early mornings, with animals kept under sheds. Intensified feeding was observed in November. No stereotypical behaviours were observed. Heart rate measurements were a pointer to the animals' emotional balance and attitudes towards people. The observed high level of horses' welfare suggested that a natural herd system of management ought to be preferred and propagated.
\end{abstract}

Keywords: herd system, horses, welfare, Hucul breed

Archiv Tierzucht 57 (2014) 24, 1-9

doi: $10.7482 / 0003-9438-57-024$

Corresponding author:

Jadwiga Topczewska; email: j.topczewska@gmail.com

Department of Animals Production and Poultry Products Evaluation, Faculty of Biology and Agriculture, University of Rzeszów, Zelwerowicza 4, 35-601 Rzeszów, Poland
Received: 11 October 2013 Accepted: 25 June 2014 Online: 29 October 2014

( 2014 by the authors; licensee Leibniz Institute for Farm Animal Biology (FBN), Dummerstorf, Germany. This is an Open Access article distributed under the terms and conditions of the Creative Commons Attribution 3.0 License (http://creativecommons.org/licenses/by/3.0/). 


\section{Introduction}

The horse population on farms, based on estimates of the Central Office of Statistics (GUS - Statistical Yearbook of Agriculture 2012), has witnessed a steady decline reaching 222210 in 2012 of which 152406 are three or more years old. The use of horses in agriculture is minimal, but their use as saddle horses, mainly for recreational and sporting purposes, has become dominant. There is a growing tendency of horses', especially primitive breeds and herbivorous species, use for landscape management, for example grazing environmentally valuable lands (Loucougaray et al. 2004, Tichit et al. 2005, Stewart \& Pullin 2008, Socher et al. 2013). Declining horse population and changes in its exploitation has encouraged social commitment aimed at improving the welfare and treatment of horses (vanDierendonck et al. 2009, Fureix et al. 2012, Visser \& van Vijk-Jansen 2012).

Animal welfare is based, according to Broom (1991) and Botreau et al. (2007), on five freedoms. Paying attention to the varied needs, i.e. nutrition, movement, relaxation and companionships, including social and reproductive as well as grooming of animals, encourages improvements in maintenance and use (Mellor \& Bayvel 2008, Tadich et al. 2008, Phillips et al. 2009, Rushen et al. 2011). Various health indicators and physiological parameters, including behaviour and productivity, serve to measure animal welfare. In an attempt to standardize different systems of evaluation, 12 criteria that complement the existing five freedoms were developed (Jones \& Manteca 2009, OIE 2009, Vapnek \& Chapman 2010). The results are accepted definitions of parameters concerning animal nutrition, maintenance and behaviour as well as animal-human relationships.

The objective of the research study was an attempt to evaluate the welfare of horses maintained in natural conditions in accordance with Welfare Quality criteria.

\section{Material and methods}

\section{Location and research material}

The research material consisted of Hucul horses maintained in natural conditions, on pastures with access to sheds that offered protection against unfavourable weather conditions. The farms are located in south-east Poland $\left(49^{\circ} 18^{\prime} 13^{\prime \prime} \mathrm{N}\right.$ and $\left.22^{\circ} 34^{\prime} 33^{\prime \prime} \mathrm{E}\right)$, an area covered by the Natura 2000 conservation Program. The prevailing climatic conditions in this area can be described as alpine with strong continental features. For about $60 \%$ of the year the area is battered with polar-marine air mass, while $26 \%$ constitute polar-continental inflows. The hottest month is July, while the coldest is February. Average annual precipitation for the area is $800-1000 \mathrm{~mm}$, of which $40 \%$ is in the summer months. Mean annual temperature is $+6^{\circ} \mathrm{C}$, reaching $+17^{\circ} \mathrm{C}$ in summer and $-6^{\circ} \mathrm{C}$ in winter. The vegetative growth period lasts about 190 days (Monthly Climate Monitoring Bulletin 2010-2012).

The pastures, on which the animals were kept, were securely protected with a wooden fence. Every quartered area had accessible water source to which the animals had unlimited access. The stocking density and pastures carrying capacity was in accordance with standards of the agri-environmental program being implemented (shocking density not exceeding 1 animal unit evaluation/ha, maximum grazing pressure not exceeding 10 animal unit evaluation/ha). 
The herd population was made up of 14 mares with their offspring and a stallion. The average age of horses in 2010 was 10.4 years. While animals made use of available pastures and were exploited based on the agri-environmental program being implemented, they were only moved to next lawn after the old area had been grazed. They were fed hay-silage in winter. Oats served as source of nutritive forage. Salt was also provided in form of salt licks. They were used as saddled horses between spring and late autumn. Foot correction and deworming were regularly carried out.

\section{Welfare evaluation criteria for horses}

The research study was conducted in the months of March, July and November 2010 and 2012. The welfare quality criteria and assumptions (Jones \& Manteca 2009) listed below were adopted for the welfare assessment:

1. Good nutrition. Access to water and feed was assessed. Health assessment was based on a five point scale (Carroll \& Huntington 1988).

2. Good housing. The stocking density and pressure of pasture were assessed while analysing their comfort at rest and freedom of movement. The herd's spatial distribution was also analysed in course of the observations. Prevailing weather conditions were also accounted for.

3. Good health. Information about the herd's healthiness was obtained by way of interview with the owner and veterinary doctor responsible for supervising the stable.

4. Appropriate behaviour. In order to assess horses' behaviour, the herd was observed fortnightly at 7.00 and 19.00. Observed types and categories of behaviour (according to McDonnell 2003) were noted using a stopwatch as well as videos and a camera. The observations were conducted by two people within a distance of between five and ten metres. The horses were accustomed to human presence. Measurements of heart rate, at rest and while daily operations were conducted by a foreign person, were done using the Polar Equine RS800CX piece of equipment to assess their emotional state.

\section{Statistical analysis}

The data were analysed statistically using the W. Shapiro-Wilk tests to determine the normality of distribution while the ANOVA tests were applied for the mean and standard deviation. The calculations were achieved using the statistical package STATISTICA 9.0 (StatSoft, Inc. Tulsa, OK, USA).

\section{Results}

Health condition of Hucul horses as an indicator of proper nutrition

The health condition of animals in a pasture management system is an indication of propriety of ad-lib feeding. It is also a key criterion in the assessment of animals' welfare. The health condition of Hucul horses ranged between $2.46 \pm 0.41$ in spring and $4.08 \pm 0.33$ in autumn (Table 1). The differences were statistically significant $(P \leq 0.01)$. 
Table 1

Evaluation results of the body condition scoring of Hucul horses according to Carroll \& Huntington (1988), in 2010 and 2012

\begin{tabular}{lccc}
\hline Months & & Years & \\
& Total & 2010 & 2012 \\
& $\overline{\mathrm{x}} \pm$ SD & $\overline{\mathrm{x}} \pm$ SD & $\overline{\mathrm{X}} \pm$ SD \\
\hline March & $2.46 \pm 0.43^{* *}$ & $2.46 \pm 0.41^{* *}$ & $2.46 \pm 0.46^{* *}$ \\
July & $3.52 \pm 0.32^{* *}$ & $3.50 \pm 0.34^{* *}$ & $3.54 \pm 0.31^{* *}$ \\
November & $4.08 \pm 0.35^{* *}$ & $4.08 \pm 0.33^{* *}$ & $4.07 \pm 0.39^{* *}$ \\
\hline
\end{tabular}

indicates difference between means at the columns $(P \leq 0.01)$

\section{Assessing maintenance conditions for Hucul horses}

Prevailing atmospheric conditions were typical for the region over the period of research. The month of March 2010 was slightly warm, while July was rather extremely hot and although higher insolation was noted in July 2012, the mean temperature was lower than the monthly average (Table 2). With the availability of about $25-30$ ha of pasture land area, the animals are guaranteed the comfort of rest and freedom of movement.

Table 2

Prevailing weather conditions in south-eastern Poland (Institute of Meteorology and Water Management)

\begin{tabular}{lccc}
\hline Years / Months & Air temperature Means, ${ }^{\circ} \mathrm{C}$ & Monthly precipitation totals, $\mathrm{mm}$ & Sunshine duration, $\mathrm{h}$ \\
\hline 2010 & & & \\
March & 3.8 & 50 & 130 \\
July & 20.7 & 200 & 240 \\
November & 6.7 & 50 & 78.4 \\
2012 & & & \\
March & 3.6 & 70 & 160 \\
July & 19.0 & 150 & 260 \\
November & 6.2 & 60 & 80 \\
\hline
\end{tabular}

The herd's health condition

Conditions of maintenance and propriety of exploitation have contributed to the attainment of high health status of the horses, with no illnesses, injuries or skin damages over the period covered by the study. The mares were characterized by high fertility and successful weaning of foals.

\section{Hucul horses and their behaviour in natural conditions}

The period of year had impact on the behaviour of horses maintained in natural conditions $(P \leq 0.01)$. Intensive feed intake and greater locomotor activities were observed in November, but in summer months when temperatures are usually higher, the same activities were rather observed in late evenings or early mornings (Table 3). Resting in a lying position by adults was occasionally observed. More time was clearly devoted to body-care treatments in July. Less frequent affiliated behaviours but slightly higher agonistic behaviours that were noted in March (Figure 1) could be linked to the proximity of mares' foaling activities in April and May. 
Table 3

Behaviour of Hucul horses maintained in natural conditions (s)

\begin{tabular}{|c|c|c|c|c|c|c|}
\hline \multirow{4}{*}{ Year / months } & \multicolumn{6}{|c|}{ Category } \\
\hline & \multirow{3}{*}{$\begin{array}{c}\text { feeding } \\
\text { and drinking } \\
\overline{\mathrm{X}} \pm \mathrm{SD}\end{array}$} & \multicolumn{2}{|c|}{ resting } & \multirow{3}{*}{$\begin{array}{l}\text { locomotion } \\
\overline{\mathrm{x}} \pm \mathrm{SD}\end{array}$} & \multirow{3}{*}{$\begin{array}{l}\text { grooming } \\
\qquad \overline{\mathrm{X}} \pm \mathrm{SD}\end{array}$} & \multirow{3}{*}{$\begin{array}{l}\text { other } \\
\overline{\mathrm{X}} \pm \mathrm{SD}\end{array}$} \\
\hline & & standing & lying & & & \\
\hline & & $\overline{\mathrm{X}} \pm \mathrm{SD}$ & $\overline{\mathrm{X}} \pm \mathrm{SD}$ & & & \\
\hline \multicolumn{7}{|l|}{2010} \\
\hline March & $22209^{A} \pm 1814$ & $10871^{\mathrm{aA}} \pm 2265$ & $2533^{A} \pm 853$ & $3551^{A} \pm 470$ & $2387^{A} \pm 568$ & $1650^{A} \pm 367$ \\
\hline July & $4140^{A} \pm 513$ & $27513^{\mathrm{aAB}} \pm 1099$ & $433^{A} \pm 621$ & $4354^{A} \pm 301$ & $4159 A^{B} \pm 912$ & $2666^{A B} \pm 393$ \\
\hline November & $24107^{A} \pm 1535$ & $8650^{a \mathrm{a}} \pm 2606$ & $523^{\mathrm{A}} \pm 737$ & $4506^{A} \pm 494$ & $3119^{B} \pm 774$ & $1845^{B} \pm 585$ \\
\hline \multicolumn{7}{|l|}{2012} \\
\hline March & $22408^{\mathrm{aB}} \pm 1649$ & $12656^{c} \pm 1857$ & $309 \pm 664$ & $3669^{B} \pm 200$ & $2554^{C} \pm 251$ & $1676^{c} \pm 356$ \\
\hline July & $4354^{B C} \pm 987$ & $28509^{C} \pm 2519$ & $257 \pm 438$ & $4204^{B} \pm 487$ & $4363^{C D} \pm 405$ & $2079 \pm 375$ \\
\hline November & $23966^{a c} \pm 138$ & $9544^{C} \pm 1607$ & $523 \pm 737$ & $4093^{B} \pm 310$ & $2786^{\mathrm{D}} \pm 448$ & $2284^{c} \pm 394$ \\
\hline
\end{tabular}

aindicates existing difference between means within the columns $(P \leq 0.05),{ }^{A B C D} P \leq 0.01$

Exploitation had influence on the level of resting heart rate, which diminished in the summer months from $52.03 \pm 6.29$ to $47.64 \pm 2.78(P \leq 0.01)$. Contacts with unfamiliar people did not result in negative emotions in horses. Lower levels of heart rate, ranging from $64.50 \pm 6.01$ to $58.96 \pm 2.70(P \leq 0.01)$, were noted in subsequent months when body-care treatments and nursing were undertaken (Table 4).

\section{agonistic $\square$ affiliation}

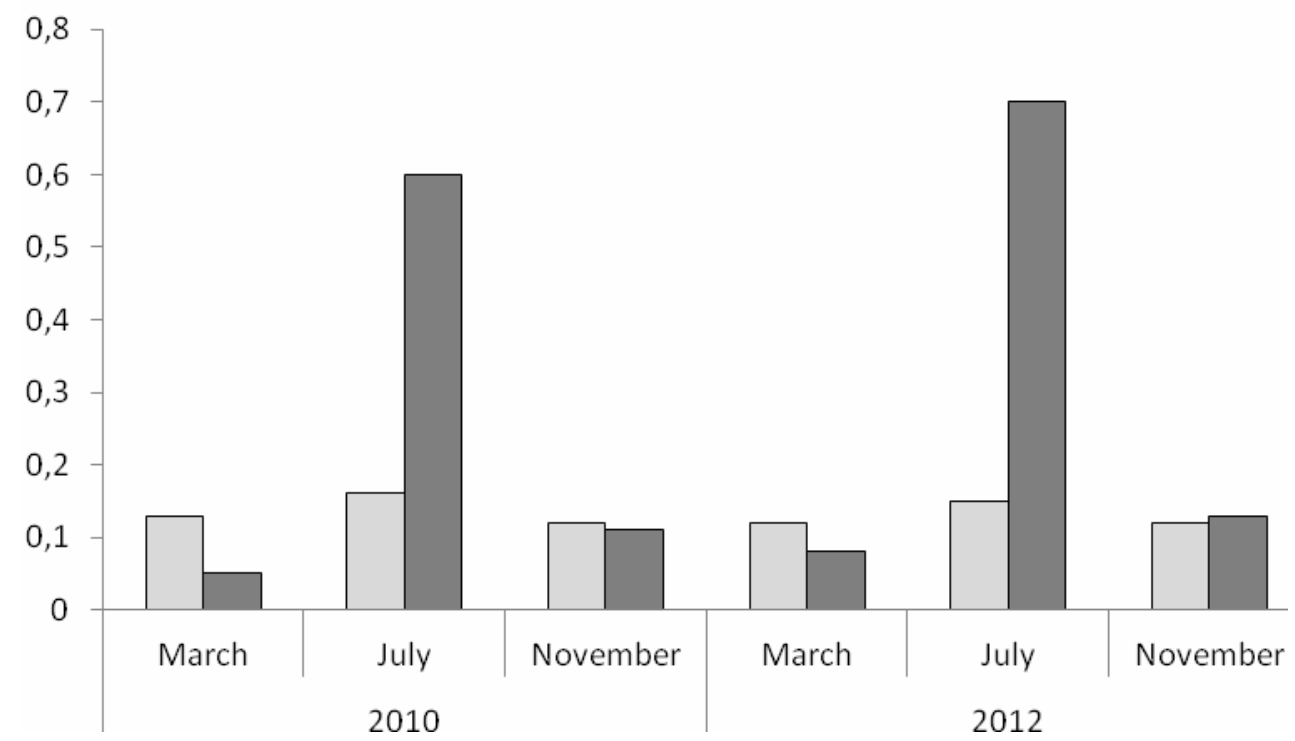

Figure 1

Frequency of agonistic and affiliation behaviours in the herd evaluated during the 2010-2012 (number/ horses/h) 
Table 4

Average heart rate of Hucul horses at rest and while being handled during the months of March, July and November 2010 and 2012

\begin{tabular}{lccc}
\hline Months & total & Years & \\
& $\overline{\mathrm{x}} \pm$ SD & 2010 & 2012 \\
& & $\overline{\mathrm{x}} \pm \mathrm{SD}$ & $\overline{\mathrm{x}} \pm \mathrm{SD}$ \\
\hline $\begin{array}{l}\text { Resting heart rate } \\
\text { March }\end{array}$ & $52.03+6.29^{\mathrm{A}}$ & $52.57+6.65^{\mathrm{A}}$ & $51.50+6.10^{\mathrm{aA}}$ \\
July & $45.71+3.90^{\mathrm{A}}$ & $45.93+4.20^{\mathrm{A}}$ & $45.50+3.74^{\mathrm{A}}$ \\
November & $47.64+2.78^{\mathrm{A}}$ & $48.14+2.85$ & $47.14+2.71^{\mathrm{a}}$ \\
Being handled heart rate & & & \\
March & $64.50+6.01^{\mathrm{B}}$ & $66.50+6.36^{\mathrm{B}}$ & $62.50+5.11^{\mathrm{B}}$ \\
July & $59.75+4.43^{\mathrm{B}}$ & $61.57+4.97^{\mathrm{B}}$ & $57.93+2.97^{\mathrm{B}}$ \\
November & $58.96+2.70^{\mathrm{B}}$ & $58.64+3.13^{\mathrm{B}}$ & $59.28+2.27$ \\
\hline
\end{tabular}

aindicates existing difference between means within the columns for $P \leq 0.05,{ }^{\mathrm{AB}} P \leq 0.01$

\section{Discussion}

Attention was paid, in course of the studies, to the propriety of horse feeding, to the need for a precise estimation of its demand, especially in animals either intensively exploited or for reproduction purposes (Martin-Rosset et al. 2006, Coenen et al. 2011). It is noteworthy, however, that the best indicator of this propriety is the animal's condition, whose assessment requires knowledge and experience (Christie et al. 2006). Dawson \& Hone (2012) provide in their studies that the regularity of this condition is depended on the productivity of pastures. Results of this research also showed that increased intensity of feed intake in November was also associated with improved conditions of the horses. The pre-winter increase in body weight could be accepted as typical for primitive races managed in natural conditions.

A herd usually has possibility of free exploration if stocking rates and pastures carrying capacities are maintained. The rest in comfort and freedom of movement criteria were fulfilled in the herd studied. Having synchronized the observed behavioural categories, no overcrowding of animals was noted. In similar studies conducted by Jaworski (2003) and Topczewska (2013), prevailing atmospheric conditions had significant impact on horses' activity in the summer. Heleski \& Murtazashvili (2010) as well as Rose-Meierhöfer et al. (2010) confirmed that horses sought shelter in sheds to avoid strong winds and intensive rainfall. The results of this research corroborate this fact as the herd only sought shelter in adverse weather conditions.

If it is assumed that the indicator of good health is the absence of trauma and injuries associated with conditions of maintenance and exploitation, then it should be noted that none of such disorders were observed in the flock over two consecutive seasons of the research. Regular de-worming and hoof correction, freedom of movement, space, as well as proper exploitation contributed to the herd's high level of health. Such a system of maintenance enhances the attainment of excellent reproductive rates (Topczewska \& Krupa 2013). It is emphasized that the most important indicator of high level of welfare is behaviour that is consistent with the specie-pattern as well as human-animal relationships (Boissy et al. 2007, Parker et al. 2008, Grandgeorge \& Hausberger 2011). In the studies conducted similar pattern-specific behavioural category was also observed (Table 3). The occurrence of 
affiliated behaviours resulted in strengthening social bonds as well as less frequent and mild forms of agonistic behaviours. The absence of stereotypes, being the result of stress due to the limitation of possibilities for the observed horses to express their natural behaviours, is noteworthy (Sergiel et al. 2012).

Personality traits, character and animal's behaviour crucial for safety of exploitation are essential to both breeders and those maintaining intimate contact with horses (Lansade \& Bouisson 2008, Graf et al. 2013). Tests of the heart rate as well as low concentration of cortisol in saliva (König von Borstel et al. 2011, Young et al. 2012) are useful in assessing the animal's emotional state, despite the susceptibility of cardiac activity to the impacts of weather conditions prevailing at the time of measurement. The results obtained from this study suggest the existence of balance in Hucul horses. Maintenance systems do not, very often, take into consideration strong desires for social contacts among horses (vanDierendonck et al. 2009, Fureix et al. 2012). Lack of exercise and social isolation are current issues that demand urgent attention. Consequent upon the prevalence of high agricultural land price, the lack of sufficient land area for pasture and paddocks has become a familiar issue on many farms with livestock.

In conclusion, maintaining a herd of horses under pasture conditions and on extensive land area can be considered optimal in ensuring the species' natural needs. The noticeable good conditions of the horses, their high state of health and the absence of stereotypes are hallmarks for a high level of welfare. Of equal importance was the evidence of proper attitude towards humans during handling and exploitation.

\section{References}

Boissy A, Manteuffel G, Jensen MB, Moe RO, Spruijt B, Keeling LJ, Winckler C, Forkman B, Dimitrov I, Langbein J, Bakken M, Veissier I, Aubert A (2007) Assessment of positive emotions in animals to improve their welfare. Physiol Behav 92, 375-397

Botreau R, Veissier I, Butterworth A, Bracke MBM, Keeling LJ (2007) Definition of criteria for overall assessment of animal welfare. Anim Welf $16,225-228$

Broom DM (1991) Animal welfare: concepts and measurement. J Anim Sci 69, 4167-4175

Carroll CL, Huntington PJ (1988) Body condition scoring and weight estimation of horses. Equine Vet J 20, 41-45

Christie JL, Hewson CJ, Riley CB, McNiven MA, Dohoo IR, Bate LA (2006) Management factors affecting stereotypies and body condition score in nonracing horses in Prince Edward Island. Can Vet J 47, 136-143

Coenen M, Kienzle E, Vervuert I, Zeyner A (2011) Recent German Developments in the Formulation of Energy and Nutrient Requirements in Horses and the Resulting Feeding Recommendations. J Equine Vet Sci 31, 219-229

Dawson MJ, Hone J (2012) Demography and dynamics of three wild horse populations in the Australian Alps. Aust Ecol 37, 97-109

Fureix C, Bourjade M, Henry S, Sankey C, Hausberger M (2012) Exploring aggression regulation in managed groups of horses Equus caballus. Appl Anim Behav Sci 138, 216-228

Graf P, König von Borstel U, Gauly M (2013) Importance of personality traits in horses to breeders and riders. J Vet Behav Clin Appl Res 8, 316-325

Grandgeorge M, Hausberger M (2011) Human-animal relationships: from daily life to animal-assisted therapies. Ann Ist Super Sanitâ 47, 397-408

GUS (2012) Statistical Yearbook of Agriculture. Central Statistical Office, Warsaw, Poland 
Heleski CR, Murtazashvili I (2010) Daytime shelter-seeking behavior in domestic horses. J Vet Sci Clin Appl Res $5,276-282$

Jaworski Z (2003) [The Polish primitive horse in a nature reserve - evaluation of the ethologic and breeding conditions]. Thesis for the degree of associate professor, University of Warmia and Mazury, Olsztyn, Poland [in Polish]

Jones B, Manteca X (2009) Welfare Quality Information Resource: First draft of an information resource. Welfare Quality Project. http://www.welfarequalitynetwork.net [last accessed 12.08.2014]

König von Borstel U, Euent S, Graf P, König S, Gauly M (2011) Equine behaviour and heart rate in temperament tests with or without rider or handler. Physiol Behav 104, 454-463

Lansade L, Bouisson MF (2008) Reactivity to humans: A temperament trait of horses which is stable across time and situations. Appl Anim Behav Sci 114, 492-508

Loucougaray G, Bonis A, Bouzillé JB (2004) Effects of grazing by horses and/or cattle on the diversity of coastal grasslands in western France. Biol Conserv 116, 59-71

Martin-Rosset W, Andrieu J, Vermorel M, Jestin M (2006) Routine methods for predicting the net energy and protein values of concentrates for horses in the UFC and MADC systems. Livest Sci 100, 53-69

McDonnell SM (2003) A Practical Field Guide to Horse Behavior: The Equid Ethogram. Hong Kong, China

Mellor DJ, Bayvel ACD (2008) New Zeland's inclusive science-based system for setting animal welfare standards. Appl Anim Behav Sci 113, 313-329

Monthly Climate Monitoring Bulletin (2010-2012) Institute of meteorology and Water Management National Research Institute, Warsaw, Poland

OIE (2008) Terrestrial Animal Health Code. 17th ed., World Organisation for Animal Health (OIE), Paris, France

Parker M, Goodwin D, Redhead ES (2008) Servey of breeders' management of horses in Europe, North America and Australia: Comparison of factors associated with the development of abnormal behaviour. Appl Anim Behav Sci 114, 206-215

Phillips CJC, Wojciechowska J, Meng J, Cross N (2009) Perceptions of the importance of different welfare issues in livestock production. Animal 3, 1152-1166

Rose-Meierhöfer S, Klaer S, Ammon C, Brunsch R, Hoffmann G (2010) Activity Behavior of Horses Housed in Different Open Barn Systems. J Equine Vet Sci 30, 624-634

Rushen J, Butterworth A, Swanson JC (2011) Animal behavior and well-being Symposium: Farm animal welfare assurance: Science and application. J Anim Sci 89, 1219-1228

Sergiel A, MaślakR, KusznierzJ, Paśko Ł (2012) [Stereotypic behavior - a review of definitions and classifications]. Med Weter 68, 45-48 [in Polish]

Socher SA, Prati D, Boch S, Müller J, Baumbach H, Gockel S, Hemp A, Schöning I, Wells K, Buscot F, Kalko EKV, Linsenmair KE, Schulze ED, Weisser WW, Fischer M (2013) Interacting effects of fertilization, mowing and grazing on plant species diversity of 1500 grasslands in Germany differ between regions. Basic Appl Ecol $14,126-136$

Stewart GB, Pullin AS (2008) The relative importance of grazing stock type and grazing intensity for conservation of mesotrophic 'old meadow' pasture. J Nat Conserv 16, 175-185

Tadich T, Escobar A, Pearson RA (2008) Husbandry and welfare aspects of urban draught horses in the south of Chile. Archiv Med Vet 40, 267-273

Tichit M, Durant D, Kernéïs $E$ (2005) The role of grazing in creating suitable sward structures for breeding waders in agricultural landscapes. Livest Prod Sci 96, 119-128

Topczewska J (2013) [Behavioral reactivity of Hucul horses managed in a herd system]. Thesis for the degree of associate professor, University of Rzeszów, Rzeszów, Poland [in Polish]

Topczewska J, Krupa W (2013) Impact of maintenance systems on the Hucul mares' reproductive rates. Arch Tierz 56, 246-254

VanDierendonck MC, de Vries H, Schilder MBH, Colenbrander B, porhallsdóttir AG, Sigurjónsdóttir H (2009) Interventions in social behaviour in a herd of mares and geldings. Appl Anim Behav Sci 116, 67-73 
Vapnek J, Chapman M (2010) Legislative and regulatory options for animal welfare. FAO Legislative Study 104 Visser EK, Van Wijk-Jansen EEC (2012) Diversity in horse enthusiasts with respect to horse welfare: An explorative study. J Vet Behav Clin Appl Res 7, 295-304

Young T, Creighton E, Smith T, Hosie C (2012) A novel scale of behavioural indicators of stress for use with domestic horses. Appl Anim Behav Sci 140, 33-43 